\section{THE STATE IN SASKATCHEWAN}

Katie Doke Sawatzky

Regina, SK

katiesawatzky@gmail.com

If you were raised in southern Saskatchewan, the word "prairie" comes naturally and you use it often to describe where you come from. For me growing up the word evoked images of yellow fields, canola dancing in the wind; the kind of landscape where your gaze is drawn upward, not towards mountains, but to the open sky. Saskatchewan is a Prairie province. I am from the prairies. I live on the prairies. Over the course of the past year, I have learned this ritual of description, so often repeated with pride, is a deception and delusion - crops, however beautiful, are not "prairie." The time has come for prairie people to acknowledge that the landscape by which they describe themselves is almost gone and that the value of what remains is threatened.

\section{Endangered and not monitored}

Temperate grasslands, which cover eight per cent of the Earth, are the most endangered ecosystem on the planet, with less than five per cent protected globally (Federal, Provincial, and Territorial Governments of Canada, 2010; Jenkins, 2009). In Saskatchewan, the figure, quoted by both the government and the conservation community, of how much native grassland is left is approximately 20 per cent. That estimate comes from a report by the Native Plant Society of Saskatchewan and is based on analysis of satellite imagery taken 24 years ago, which says the amount left is most likely a range of between 17 and 21 per cent (Hammermeister, Gauthier, \& McGovern, 2001).

Saskatchewan's Ministry of Environment does not know how much native prairie is left and finding out is no easy task. There is no active provincial reporting or monitoring of the landscape by the province. In 2015, the ministry began the Prairie Landscape Inventory, which aims to find out how much native prairie is left. The ministry is currently testing modelling techniques in different areas of the province that will be able to differentiate native grass from tame grass in satellite imagery, something that is not done in other data products like the land-cover maps created by Agriculture and Agri-Food Canada. However, Ben Sawa, a habitat ecologist with the ministry, estimates the process will take anywhere from five to 10 years. In the meantime, more parcels of grassland are lost each year.

\section{An eroding landscape}

Agriculture and Agri-Food Canada cropland inventory maps, while not able to distinguish native from tame grassland, show a steady decline of grassland from 1990 through to 2015. Defining grassland as "Predominantly native grasses and other herbaceous vegetation, may include some shrubland cover," an analysis of the maps by University of Regina geography professor Joe Piwowar shows a decline of 3.3 million acres over 25 years (Agriculture and Agri-Food Canada, 2015). As of 2015, 8.2 million acres of grassland remained in the province, which means that, out of the historical 60 million acres the Prairie ecozone once encompassed in Saskatchewan, only 13.7 per cent remains. This is 6.3 per cent less than what is currently quoted by the Ministry of Environment and Nature Conservancy of Canada Saskatchewan Region.

A 2014 study done on fragmentation in the Canadian Prairie ecozone, calculates a range of remaining prairie land-cover types and, if sticking strictly to grassland (not including cover types like fallow and hay/pasture), concludes that there are 9.1 million acres left in Saskatchewan, which brings the figure remaining down to 15 per cent, more evidence of grassland's steady decline (Roch \& Jaeger, 2014).

While grassland conversion to cropland isn't what it used to be during settlement, it is still happening, something AAFC data also confirms. A simple search on the AAFC Land Use interactive map indicates that an average of 2.4 million acres of grassland were converted to cropland from 1990 to 2000 and from 2000 to 2010 (the land use inventory is only taken every 10 years) in the Prairie provinces. Here, the definition of "grassland" in the land use data specification is: "Natural grass and shrubs used for cattle grazing" (Agriculture and Agri-Food Canada, 2010). The World Wildlife Fund's 2017 Plowprint Report, which uses the AAFC data maps in its measurement of grassland conversion to cropland, confirmed the trend by stating that the highest rates of grassland conversion in the Northern Great Plains were in Saskatchewan and Alberta. The highest rates of conversion in the Great Plains, which extends from Saskatchewan to Mexico, were also found in Saskatchewan, in the aspen parkland, the transitional zone between the grassland and boreal forest. 


\section{Alberta miles ahead on monitoring ecosystems}

Knowing a more accurate amount of native prairie left in Saskatchewan may not seem important to a now primarily urban Saskatchewan public (a 2011 census described only 30 per cent of the population as rural). On the flip side, it may be imperative, given that fewer people are living close to native prairie than ever before, meaning fewer eyes watching for changes in the landscape. Having that frontline information and more broad-scale provincial biodiversity monitoring helps government make informed policy decisions and keep the public up-to-date on human impacts on ecosystems. Such monitoring isn't a pipe dream. Saskatchewan's western neighbour, Alberta, has been forging a path in world-class ecosystem monitoring since 2007. The Alberta Biodiversity Monitoring Institute, an independent, arms-length, not-for-profit organization, funded by government, universities, and industries like energy and agriculture, releases an annual biodiversity monitoring report and a biannual report on the human footprint in each natural ecoregion of the province.

ABMI has a total of 1,656 site locations that are actively monitored across the province, with around 600 sites in the Prairie region. The sites are 20 kilometres apart and visited annually, where staff measure plant growth, monitor species, percentage of different land-covers like water or trees, and complete soil analysis. They take photographs of the site and send any data about unknown species to taxonomic experts at the Royal Alberta Museum.

Majid Iravani, an applied ecologist at $A B M I$, said that while using satellite data for land-cover mapping is the protocol around the world, you need on-the-ground assessment to

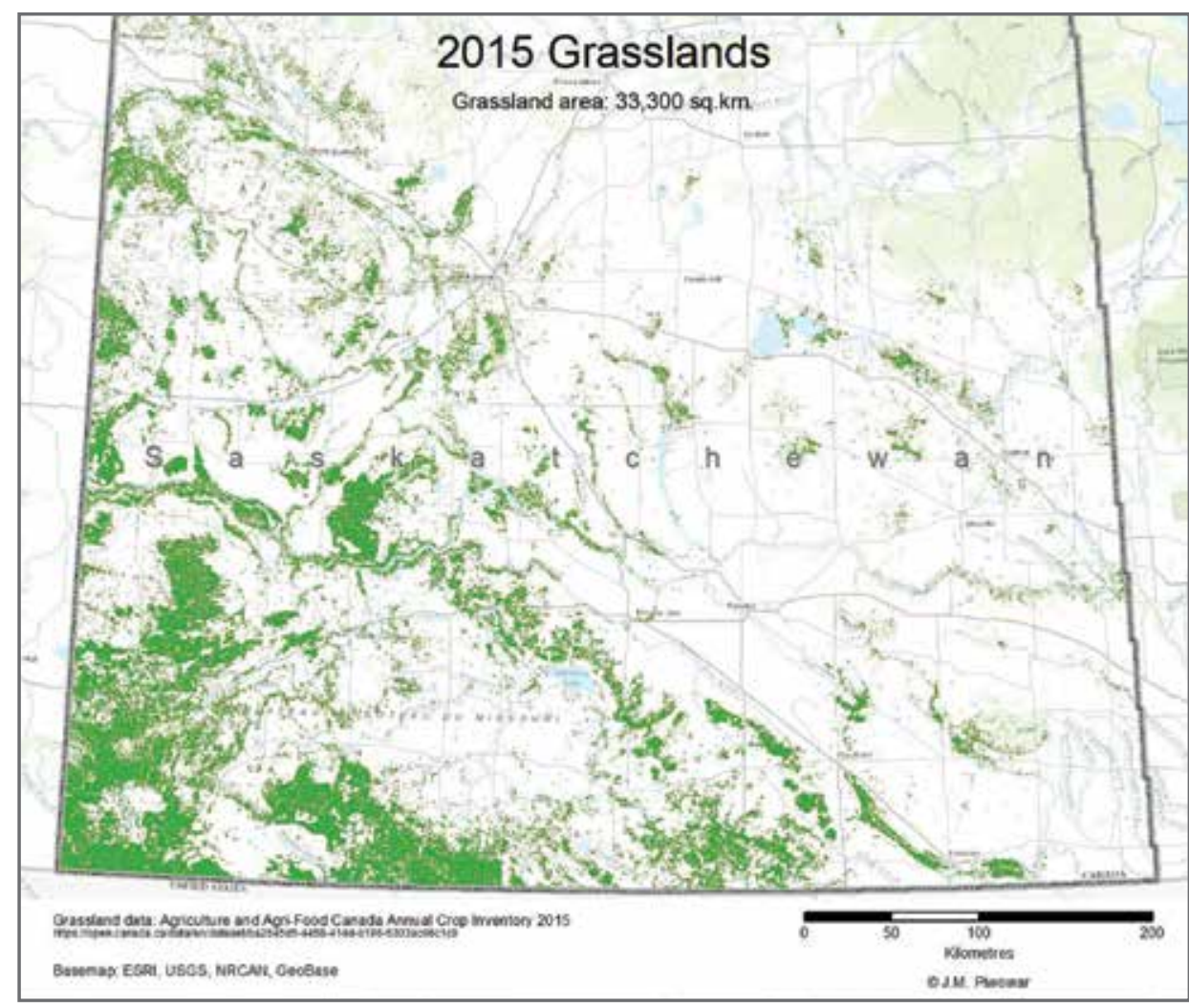

Grassland cover in Saskatchewan in 2015 was 8.2 million acres. Considering the prairie ecoregion in the province is 60 million acres, as of 2015, grassland covered only 13.7 per cent of its historic area, a 6.3 per cent drop from Hammermeister's 2001 estimate of 20 per cent. Map created by Joe Piwowar.

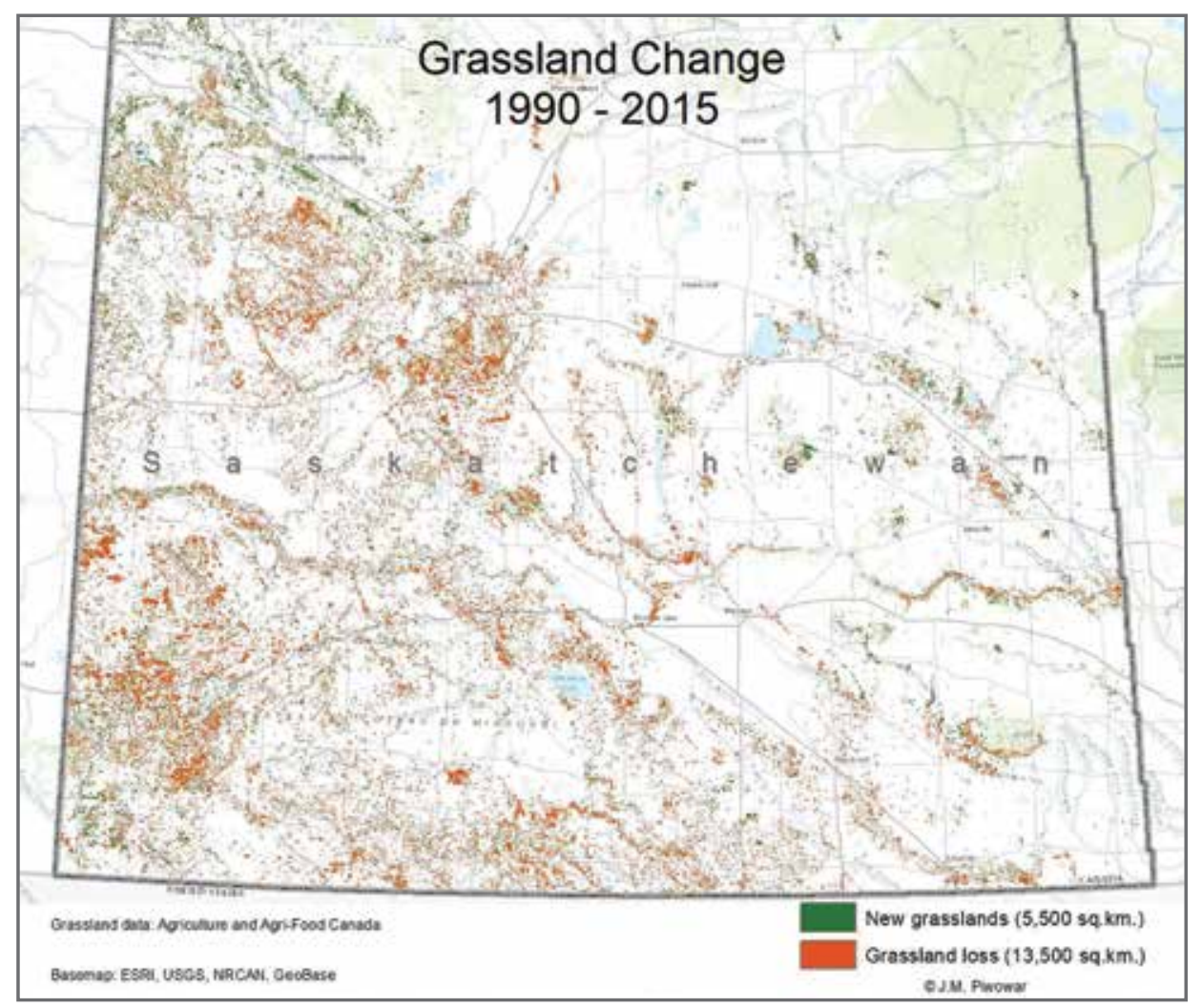

From 1990 to 2015, 3.3 million acres of grasslands were lost, most likely due to cultivation. New grasslands have emerged along the northern borders of the agricultural region are likely due to pasture expansion into forests. Map created by Joe Piwowar. 
validate geospatial data, especially if you're trying to gauge how much native prairie is left on a smallerscale, like in a township, or quartersection.

"When you want to implement something, like, land-conversion protocol, for example, ... you really need detailed data, you really need data that you can trust," said Iravani.

Iravani also says the benefit of this kind of systematic monitoring is that it provides a baseline of biodiversity from which patterns of change can be tracked over time.

"A monitoring program at this scale is important because especially for an area like Canada, we don't know much about our biodiversity," he said. "As long as we don't know what we have, we can't really manage it or protect it. We need to ... understand what we have and then we need to assess what would be the reaction of these resources in terms of climate change or any land development and so on."

As it stands right now, according to ABMI's data, the grasslands region, which takes up 14 per cent of Alberta, has a human footprint of 57 per cent, as of 2017, meaning only 43 per cent is untouched by human disturbance. Within that 57-per-cent footprint, agriculture has done the most damage by far at 50 per cent, with things like energy and transportation following at 2.5 per cent. The parkland region, which is the transitional area between the grasslands and boreal forest, has seen even more human disturbance, with agriculture taking up 68 per cent of the region and an overall human footprint of 78 per cent. Iravani says discerning the exact

\section{Crown land sold since 2008}

\section{By Saskatchewan's Ministry of Agriculture}

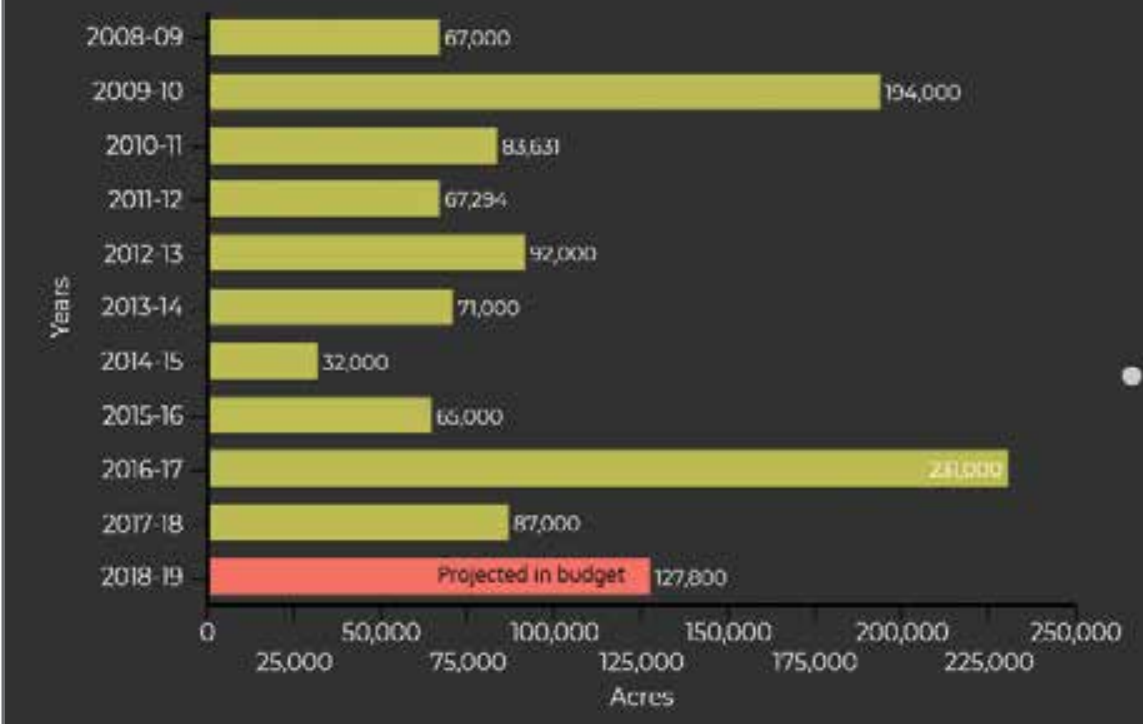

Over the past ten years, the Saskatchewan government has sold 989,925 acres of Crown land With no provincial monitoring system in place, the govermment does not know how much native prairie has been sold or cultivated as a result of these sales. The trend is set to continue. Projected revenue in the Saskatchewan provincial budget from Crown land sales for $2018-2019$ is $\$ 63.9$ million, or, using the program average of, 127,800 acres.

Number's supplied by Govemment of Saskatchewan.

amount of native prairie left within these regions is difficult because of the difficulty of differentiating tame pastures, native pastures, and cropland. He says ABMI hasn't found a way to map Alberta's exact amount yet, but that subtracting the human footprint from the original geographical area gives them a pretty good idea. Doing the math, with 57 per cent of 24 million acres of grasslands under human footprint, only 10 million acres remain, or 43 per cent. In the parkland region, that number drops to 22 per cent.

\section{The threat of government disinterest}

After record Crown land sales in the 2007-2008 budget year, the Saskatchewan government shifted to incorporate its selling of Crown land as a non-renewable revenue source in its 2008-2009 provincial budget, alongside natural gas, oil and potash. Since 2008, the Ministry of Agriculture has offered incentives for agricultural producers to purchase the Crown land they have been leasing from the provincial government. From 2008 to 2014, 500,000 acres of Crown land were sold under the Agricultural Crown Land Sale Program. Another incentive program began in 2015 offering leaseholders a 15 per cent discount, with the ministry estimating at the time that 600,000 acres would be sold under the program.

What is the connection with native prairie in Saskatchewan? With no provincial monitoring system in place, the government does not know how much native prairie has been sold or cultivated as a result of these sales.

Wally Hoehn, director of the lands branch for Saskatchewan's Ministry of Agriculture, says that a random sampling of past sales doesn't indicate that a significant amount of Crown land sold by the ministry has 
been converted to agriculture. He's confident producers are good stewards and doesn't consider agriculture a big threat in today's world.

"There is a bit of ... the perception that as soon as a client gets this land they're going to rip it up and tear it up. No, these guys are strong stewards," said Hoehn. "They've done it because they know it's the right thing to do and they continue to do the right thing ... whether it's under a Crown lease or whether it's under private ownership."

But Hoehn also says once Crown land is sold, the ministry no longer knows whether native prairie will remain and that he currently doesn't know how much native prairie has been sold through Crown land sales.

"It would take a lot of time to sort those (numbers) out," he said.

Despite Hoehn's confidence, the grassland decline and conversion captured by AAFC data and the World Wildlife Fund in Saskatchewan show a different story. Combine this with the facts that the Ministry of Agriculture only audits or monitors its leased grassland at the time of lease renewal or when there's a complaint and that no provincial monitoring of native prairie is undertaken by the Ministry of Environment, it's not a surprise that grassland continues to degrade, slowly but surely.

Hoehn says the ministry currently relies on the public to do monitoring.

"Our best monitors are people out in the public, who know that it's Crown land and know what can and can't go on on it," he said. "They will call us and say we don't think this should be going on in there and we'll go out there and do an inspection."

The Saskatchewan government has also shown a disinterest in supplying pasture management on its own Crown land.
In 2013, a year after the federal government announced it was cutting the Prairie Farm Rehabilitation Administration's Community Pasture Program (PF pastures) from its budget and returning the pastures to the Prairie provinces, the Saskatchewan government decided to lease each of its 62 pastures separately, a landbase of 1.8 million acres (the majority of which is native grassland). Instead of continuing the PF program's thirdparty management, the province is leasing to patron groups who incorporated into businesses, ending the legacy of the community-pasture model, which provided world-class sustainable management of the grasslands. The PF transition ended on April 1, 2018.

In the spring of 2017, the Saskatchewan government cut the provincial Saskatchewan Pastures Program, which was even older than the PF system and responsible for 50 pastures, totalling 780,000 acres. According to provincial government, since 1922, when the SPP started, "the agriculture industry has become a strong driver of Saskatchewan's economy, and the program is no longer necessary." The SPP pastures are currently transitioning to a 15year long-term lease arrangement with patrons, similar to the PF pastures.

\section{Legislation offers little protection}

Native prairie in Saskatchewan is protected by legislation like conservation easements, which place legal restrictions on the title of a piece of land that protect its natural ecosystems, restrictions such as no cultivation or new buildings. The Wildlife Habitat Protection Act protects designated Crown lands with ecological value from being sold. But in 2010, the
Ministry of Agriculture amended the WHPA so that lands held under its legislation could be assessed and possibly sold, depending on their "ecological value." In 2014, the ministry determined while land with "high ecological value" cannot be sold, lands with "moderate ecological value" can be sold with a Crown conservation easement (easements held by the Crown, not the landowner), and lands with "low ecological value" can be sold with no restrictions. Landowners can appeal to have Crown conservation amendments on their lands amended or terminated, and the minister, according to The Conservation Easements Act, can accept the application if he "is satisfied that it is in the public interest to do so."

When asked why all Crown land sold in Saskatchewan's prairie region isn't protected with easements considering the endangered state of temperate grasslands, Hoehn said he doesn't consider all parcels of high ecological value just because of that fact.

"I've been in arguments where they'll argue that a road allowance is high ecological value. I mean it's all got to be relative and in perspective is how I look at it," said Hoehn. "I mean there's a desire from our clients to quit leasing this land and get some equity in it ... We looked at our inventory and said, 'Okay there is this group in the middle that is moderately important. We think we can sell 'em and we'll put a Crown conservation easement on it."'

In 1997, Saskatchewan's Ministry of Environment launched the Representative Areas Network (RAN). The goal of RAN is to conserve 12 per cent in each of the 11 ecoregions in the province.

"Each designated site helps to conserve Saskatchewan's native biological diversity and will be used 


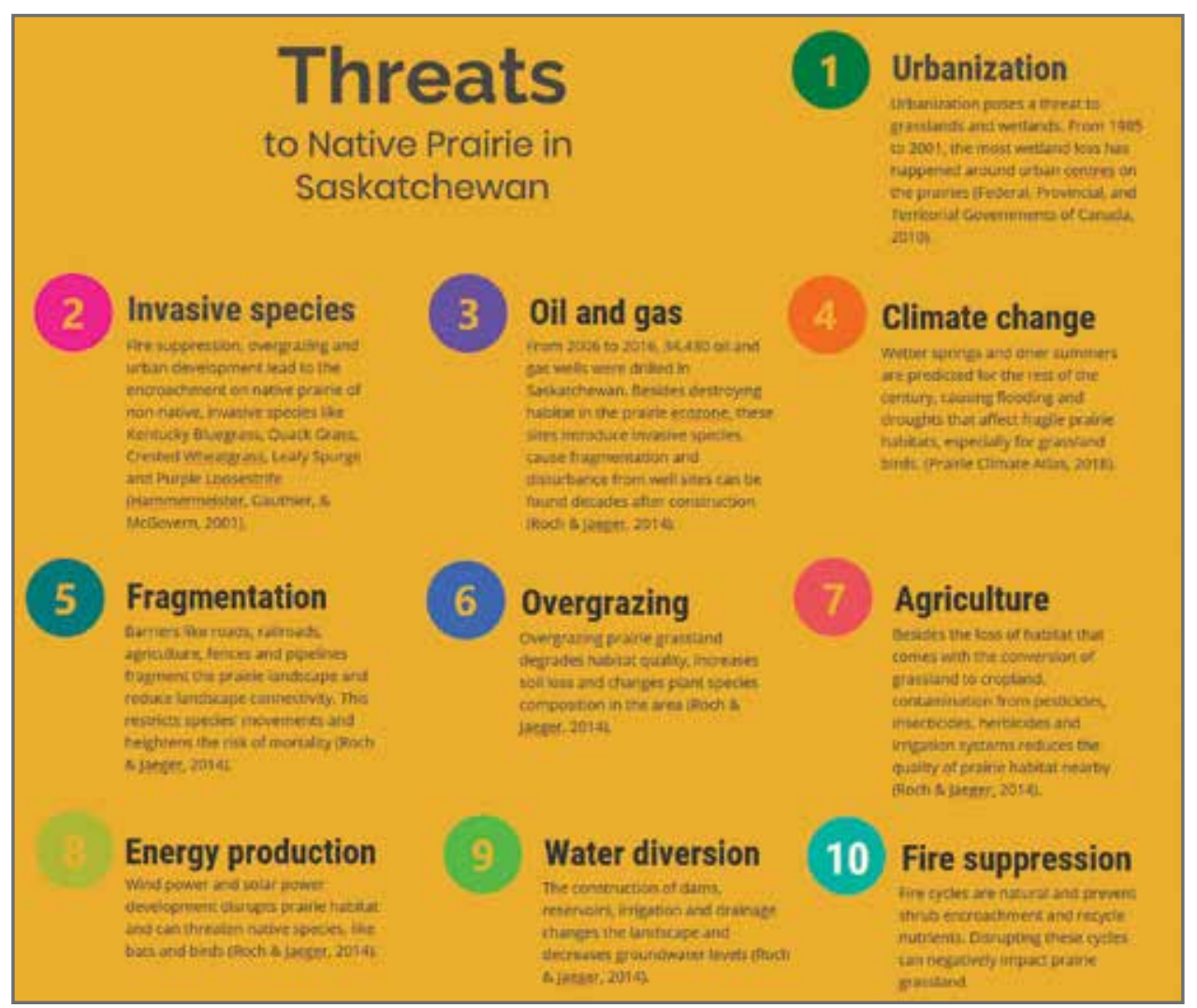

to benchmark or as a control area when assessing ecological health in areas outside of the representative area sites," states Sawa.

Currently, the province conserves only 5.9 per cent of moist-mixed grassland and 5.6 per cent of aspen parkland, two ecoregions in the prairie ecozone. Not only does this fall short of RAN's own goal but also of national and international conservation targets. Nineteen of the Aichi targets, set in 2010 by the United Nation's Convention on Biological Diversity, were adopted by Canada in 2015. The eleventh target aims to protect at least 17 per cent of all terrestrial and inland waters. According to Jennifer McKillop, a former official with the Ministry of Environment and now the director of conservation for Nature Conservancy of Canada Saskatchewan, Saskatchewan hasn't reached nine per cent.

\section{Works Cited}

Agriculture and Agri-Food Canada. (2015). Annual space-based crop inventory for Canada. Centre for Agroclimate, Geomatics and Earth Observation. Retrieved from http://www.agr.gc.ca/atlas/ supportdocument_documentdesupport/ annualCroplnventory/en/ISO\%2019131_ AAFC_Annual_Crop_Inventory_Data_ Product_Specifications.pdf

Agriculture and Agri-Food Canada. (n.d.). ISO 19131 - Land use 1990, 2000, 2010, Data product specifications. Retrieved from http://www.agr.gc.ca/atlas/ supportdocument_documentdesupport/ aafcLand_Use/en/ISO_19131_Land_ Use_1990_2000_2010_Data_Product_ Specifications.pdf

Federal, Provincial, and Territorial Governments of Canada. (2010). Canadian biodiversity: Ecosystem status and trends 2010. Ottawa: Canadian Councils of Resource Ministers. Retrieved from http://www.biodivcanada.ca/A519F0008427-4F8C-9521-8A95AE287753/ EN_CanadianBiodiversity_FULL.pdf

Hammermeister, A., Gauthier, D., \& McGovern, K. (2001). Saskatchewan's native prairie: statistics of a vanishing ecosystem and dwindling resource. Saskatoon: Native Plant Society of Saskatchewan. Retrieved from https://www.npss.sk.ca/docs/2_pdf/ NPSS_SKNativePrairie-TakingStock.pdf
Jenkins, C. \& Joppa, L. (2009). Expansion of the global terrestrial protected area system. Biological Conservation 142 (10), 2166-2174. Retrieved from https://doi. org/10.1016/j.biocon.2009.04.016

Johnston, M. (2017, January 27). Wetlands and carbon: Filling the knowledge gap. Saskatchewan Research Council. Retrieved from: https://www.src.sk.ca/blog/wetlandsand-carbon-filling-knowledge-gap

Mosher, D. (2012, March 22). Grasslands more diverse than rain forests: In small areas. National Geographic. https://news.nationalgeographic.com/ news/2012/03/120320-grasslands-rainforests-species-diversity-environment/

Roch, L. \& Jaeger, J. (2014). Monitoring an ecosystem at risk: What is the degree of grassland fragmentation in the Canadian Prairies? Environmental Monitoring and Assessment 186(4), 2505-34. doi:http:// dx.doi.org.libproxy.uregina.ca:2048/10.1007/ s10661-013-3557-9

Vaadeland, G. \& Richardson, K. (2016, March 21). Grasslands, forests \& wetlands Nature's carbon capture \& storage solution. Canadian Parks and Wilderness Society. Retrieved from http://cpaws.org/blog/ grasslands-forests-wetlands-natures-carboncapture-storage-solution

World Wildlife Fund. (2017). World Wildlife Fund 2017 Plowprint Report. World Wildlife Fund Northern Great Plains Program. Retrieved from https://c402277.ssl.cf1. rackcdn.com/publications/1103/files/origina/ plowprint_AnnualReport_2017_revWEB_ FINAL.pdf?1508791901

Wruck, G.W. \& Gerein, K.M. (2003). Native plants, water and us! Native Plant Society of Saskatchewan Inc. Saskatoon: Native Plant Society of Saskatchewan Inc.

Katie Doke Sawatzky was the recipient of the Margaret Skeel Graduate Scholarship in 2018 and is a Master of Journalism graduate from the University of Regina. Her research focus was native prairie in Saskatchewan and she remains interested and passionate about environmental issues in the province. She lives in Regina with her husband and two children and is currently working for Mennonite Church Canada. 